\title{
DISTRIBUȚIA SPECIEI ENDEMICE DIN CRIMEEA BREPHULOPSIS CYLINDRICA (MOLLUSCA, GASTROPODA, ENIDAE) ÎN AFARA AREALULUI NATIV
}

\author{
Coadă Viorica, Ţîgănaș Ana \\ Universitatea de Stat din Tiraspol, Chișinău, Republica Moldova, \\ vioricacoada@gmail.com
}

https://doi.org/10.53937/9789975315975.37

Orașele pot servesc drept rampă de lansare pentru distribuția speciilor care depășesc cu mult arealul lor: pe de o parte fluxul de trafic, iar pe de altă parte, temperatura aerului din oraș este întotdeauna mai mare, ce oferă posibilitatea de trai a speciilor sudice. Răspândirea moluștelor terestre este în legătură cu transportarea lor directă, prin intermediul materialelor de construcție sau de plantare, solului, etc.

Pentru prima dată specia Brephulopsis cylindrica este descrisă în lucrarea lui A.Schileyko (1984), unde este indicat faptul că această specie a fost introdusă în diferite localități din R. Moldova. Specia face parte din familia Enidae arealul căreia cuprinde Europa, cu excepția regiunilor Nord, Africa de Nord, Caucaz, Asia Centrală și de Sud-Est și Japonia. B. cylindrica este un gastropod nativ din Crimeea, arealul căreia se extinde spre nord și vest.

În sectorul Telecentru al orașului Chișinău, lângă artera de transport de pe strada Grenoble (coordonatele geografice $46^{\circ} 59^{\prime} 02.8^{\prime \prime} \mathrm{N}$ $28^{\circ} 50^{\prime} 04.9^{\prime \prime} \mathrm{E}$ ) a fost identificată o populație a acestei specii. Unele semne indică faptul că populația există cel puțin de câțiva ani. În vegetația ierboasă a acestei pajiști predomină speciile Reseda lutea, Plantago lanceolata, Trifolium pratense, Elytrigia repens, Achillea millefolium, Erigeron annuus, Silene vulgaris, Lamium purpureum, Senecio jacobea etc. Pe alocuri se întâlnesc și arbori de ulm, nuc și salcâm.

Această specie prezintă următoarele caracteristici morfologice: cochi- 
lia conic-cilindrică sau cilindrică cu partea superioară conică, cu pereți duri, cu striațiuni fine, de culoare albă monocromatică sau cu dungi întunecate. Anfracte 9-10 sunt slab convexe. Apertura ovală, ușor oblică. Marginea exterioară este dreaptă în partea de sus, rotunjită ușor în partea de jos. Buza este subțire, albă. Ombilicul îngust. Înălțimea cochiliei este de 23-30 mm, lățimea cochiliei este de 7-10 mm (Shileiko, 1984).

Specia se caracterizează printr-o variabilitate considerabilă cu referire la culoarea și forma cochiliei. Parametrii conchiologici de bază la populația studiată se caracterizează prin următoarele caracteristici ale cochiliei:

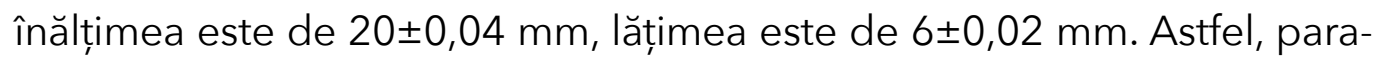
metrii de mărime ai cochiliei diferă de cei indicatți în literatură, ce poate fi explicată prin influența climatului mai rece. Densitatea medie calculată este de $90 \mathrm{ex} / \mathrm{m}^{2}$, raportul dintre formele mature și juvenile este de 40,5\% mature și respectiv 59,5\% (data colectării 20.07.2018). Particularitățile extinderii arealului la specia dată este condiționată de plasticitatea ecologică înaltă și influența factorului antropic în răspândirea ei. 